\title{
Obtaining Alumina from Kaolin Clay via Aluminum Chloride
}

\author{
Vyacheslav I. Pak ${ }^{1}$, Sergey S. Kirov ${ }^{1}$, Anton Yu. Nalivaiko ${ }^{2, * \mathbb{D}}$, Dmitriy Yu. Ozherelkov ${ }^{2} \mathbb{D}$ and
} Alexander A. Gromov ${ }^{2}$

1 Department of Non-ferrous Metals and Gold, National University of Science and Technology MISIS, Moscow 119991, Russia; pakvi@misis.ru (V.I.P.); kirovs13@yandex.ru (S.S.K.)

2 KINETICA Engineering Center, National University of Science and Technology MISIS, Moscow 119991, Russia; d.ozherelkov@gmail.com (D.Y.O.); a.gromov@misis.ru (A.A.G.)

* Correspondence: nalivaiko@misis.ru; Tel.: +7-499-700-0306 (ext. 50703)

Received: 26 October 2019; Accepted: 25 November 2019; Published: 28 November 2019

\begin{abstract}
A method of alumina production based on hydrochloric acid processing of kaolin clays from the East Siberian deposits was studied. Hydrochloric acid leaching was carried out at $160^{\circ} \mathrm{C}$. The leaching solution was subjected to a two-stage crystallization of aluminum chloride hexahydrate $(\mathrm{ACH})$. The precipitated crystals were calcinated in air at a temperature above $800{ }^{\circ} \mathrm{C}$ to produce alumina. The main part of water and chlorine during thermal decomposition of $\mathrm{ACH}$ was removed at $400{ }^{\circ} \mathrm{C}$. The influence of temperature and duration of $\mathrm{ACH}$ calcination on the residual chlorine content in alumina was studied. The optimal temperature of $\mathrm{ACH}$ calcination was $900{ }^{\circ} \mathrm{C}$ with a duration of $90 \mathrm{~min}$. It was shown that the increase in calcination temperature contributed to the decrease in chlorine content in the final product. However, an increase in calcination temperature above $900{ }^{\circ} \mathrm{C}$ led to the transition of the well-soluble $\gamma-\mathrm{Al}_{2} \mathrm{O}_{3}$ phase to the insoluble $\alpha-\mathrm{Al}_{2} \mathrm{O}_{3}$, which negatively affected the further electrolysis of aluminum. The size of alumina particles was not affected by the calcination mode. The rate of dissolution of the prototype $\mathrm{Al}_{2} \mathrm{O}_{3}$ in $\mathrm{Na}_{3} \mathrm{AlF}_{6}$ was higher than for the alumina obtained by the classical method. Alumina content, particle morphology, and particle size distribution for the obtained alumina were studied by X-ray diffraction (XRD), scanning electron microscopy (SEM), and laser diffraction methods. The obtained alumina is suitable for aluminum production according to the studied characteristics.
\end{abstract}

Keywords: alumina; aluminum chloride hexahydrate; hydrochloric acid process; leaching; physico-chemical properties

\section{Introduction}

Nowadays, the Bayer process is the predominant method of alumina production in the world. This method is based on the leaching of pre-crushed bauxite in alkaline solutions. After leaching, aluminum hydroxide separates from the aluminate solution and is then calcinated to produce alumina. High-quality bauxites with an $\mathrm{Al}_{2} \mathrm{O}_{3}$ to $\mathrm{SiO}_{2}$ mass ratio of more than 8 are required as a raw material for alumina production by the Bayer process [1]. The world's reserves of high-quality bauxite reduce every year [2-4]. In this regard, a lot of intensive research focused on the expanding of the raw material base with the involvement of the low-quality aluminum raw materials (high-silica bauxite, kaolin clay, nepheline, ash) has been carried out [5-8].

The development of highly-efficient processing methods of low-quality aluminum raw materials with high silica content is an urgent task. One of the possible ways of high-silica raw materials processing is the sintering method. However, this method is multi-stage and characterized by high complexity as well as high fuel and reagents consumption. 
One of the most promising methods of obtaining alumina from high-silica aluminum ores is a hydrochloric acid technology, followed by the selective separation of aluminum compounds from acidic solutions [9-11]. The main advantage of this technology is the removal of silicon oxide at the first stage of the process. Silica separation helps to simplify the process and prevent the formation of harmful alumina production waste [12-14]. The advantage of hydrochloric acid as a leaching agent is the possibility of aluminum chloride hexahydrate $(\mathrm{ACH})$ selective precipitation from leaching solutions. In addition, the hydrochloric acid method is the easiest in terms of acid regeneration compared to sulfuric and nitric acids. $[15,16]$. After the thermohydrolysis of aluminum chloride and iron crystals, gaseous $\mathrm{HCl}$ is captured by water and returned to leaching.

The purpose of this research is the study of the physical and chemical properties of alumina obtained by the hydrochloric acid technology using kaolin clays from Eastern Siberia, as well as the assessment of the obtained alumina suitability for aluminum electrolysis.

\section{Materials and Methods}

\subsection{Materials}

A sample of kaolin clay from the East Siberian deposits was used as the raw material for alumina production. Table 1 shows the chemical composition of kaolin clay by the X-ray diffraction (XRD) method.

Table 1. The chemical composition of kaolin clay.

\begin{tabular}{cccccccccc}
\hline Component & $\mathrm{SiO}_{2}$ & $\mathrm{Al}_{2} \mathrm{O}_{3}$ & $\mathrm{Fe}_{2} \mathrm{O}_{3}$ & $\mathrm{TiO}_{2}$ & $\mathrm{CaO}$ & $\mathrm{Na}_{2} \mathrm{O}$ & $\mathrm{K}_{2} \mathrm{O}$ & $\mathrm{MgO}$ & Loss on Ignition \\
\hline Content, wt \% & 50.71 & 28.77 & 6.14 & 0.42 & 0.43 & 0.18 & 0.23 & 0.72 & 12.40 \\
\hline
\end{tabular}

The initial samples of kaolin clay consisted of more than $50 \%$ silica, the content of aluminum oxide in the sample was $28.77 \%$. Kaolin clay also contains oxides of iron, titanium, calcium, sodium, potassium, and magnesium. Experiments were carried out using hydrochloric acid (37 vol \%). The required concentration of hydrochloric acid in the leaching process was achieved by diluting with distilled water. Hydrogen chloride gas was used in the crystallization process.

\subsection{Characterization}

Thermal analysis of the $\mathrm{AlCl}_{3} \cdot 6 \mathrm{H}_{2} \mathrm{O}$ samples was performed using the STA $409 \mathrm{CD}$ thermal analyzer (Netzsch Group, Selb, Germany) with a sample heating rate of $10{ }^{\circ} \mathrm{C}$ per minute in an argon gas atmosphere. The Vega LMH electron scanning microscope (Tescan, Brno, Czech Republic) with the Oxford Instruments Advanced AZtecEnergy analysis attachment (Asylum Research, NanoAnalysis, High Wycombe, UK) was used for the scanning electron microscopy (SEM) analysis of ACH crystals. Studies of the granulometric composition of alumina were carried out using the Microsizer-201S laser particle analyzer (Scientific instruments Jsc., Saint Petersburg, Russia). XRD of alumina was carried out using the D8 Advance equipment (Bruker Corp., Billerica, MA, USA).

\subsection{Experimental Research}

The technological scheme of the hydrochloric acid method for alumina production from kaolin clays is shown on Figure 1.

Leaching of kaolin clay was carried out for $3 \mathrm{~h}$ at $160{ }^{\circ} \mathrm{C}$ in an autoclave. Hydrochloric acid (20 vol \%) was used as a leaching agent. The pulp after leaching was used for the thickening and filtering of Si-stoff. Si-stoff with a residual moisture content of $40-50 \mathrm{wt} \%$ was washed with water, which aimed to absorb $\mathrm{HCl}$ from the calcination gases. This process was followed by the obtainment of circulating acid. After washing, Si-stoff was sent for drying, and it can be used as a product for cement manufacturing. 


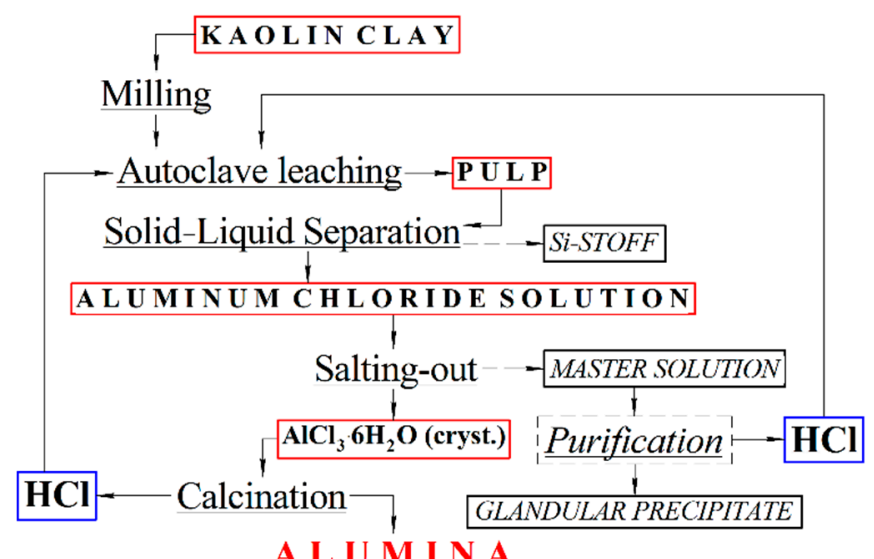

A L U M I N A

Figure 1. Technological scheme of alumina production from kaolin clays.

After Si-stoff separation, the aluminum chloride solution was crystallized [17-21]. The process was carried out by saturating the aluminum chloride solution with gaseous $\mathrm{HCl}$. Crystallization of $\mathrm{AlCl}_{3} \cdot 6 \mathrm{H}_{2} \mathrm{O}$ was conducted in two stages. The first stage of crystallization was carried out at a temperature of $20^{\circ} \mathrm{C}$ for $45 \mathrm{~min}$ in order to achieve a maximum degree of $\mathrm{ACH}$ crystallization (up to $97 \%$ ). The crystals deposited at the first stage were recrystallized for $45 \mathrm{~min}$ to obtain crystals with low impurity content. $\mathrm{AlCl}_{3} \cdot 6 \mathrm{H}_{2} \mathrm{O}$ crystals were calcinated in a tubular rotary furnace at a temperature of $900-1100{ }^{\circ} \mathrm{C}$ for $90 \mathrm{~min}[22,23]$.

An electrochemical cell was developed in order to determine the dissolution rate of $\mathrm{Al}_{2} \mathrm{O}_{3}$ in $\mathrm{Na}_{3} \mathrm{AlF}_{6}$. The scheme of this cell is shown in Figure 2. The graphite crucible was chosen as the basis for the electrochemical cell due to the stability in the aggressive molten cryolite salts [24-26]. The graphite crucible was enclosed in a steel casing and alumina backfill was located in the space between the crucible and casing. Graphite rods $(0.5 \mathrm{~cm} \times 14 \mathrm{~cm})$ were used as electrodes. The measuring rod was installed in order to adjust the interelectrode distance between the electrode holders. The melt temperature was controlled by a platinum-platinum rhodium thermocouple. The GW PSW7 30-72 power source (GW instek, Taiwan) was used as a direct current (DC) power supply. The cell was heated using the KC 2/15 muffle furnace (Nabertherm GmbH, Lilienthal, Germany).

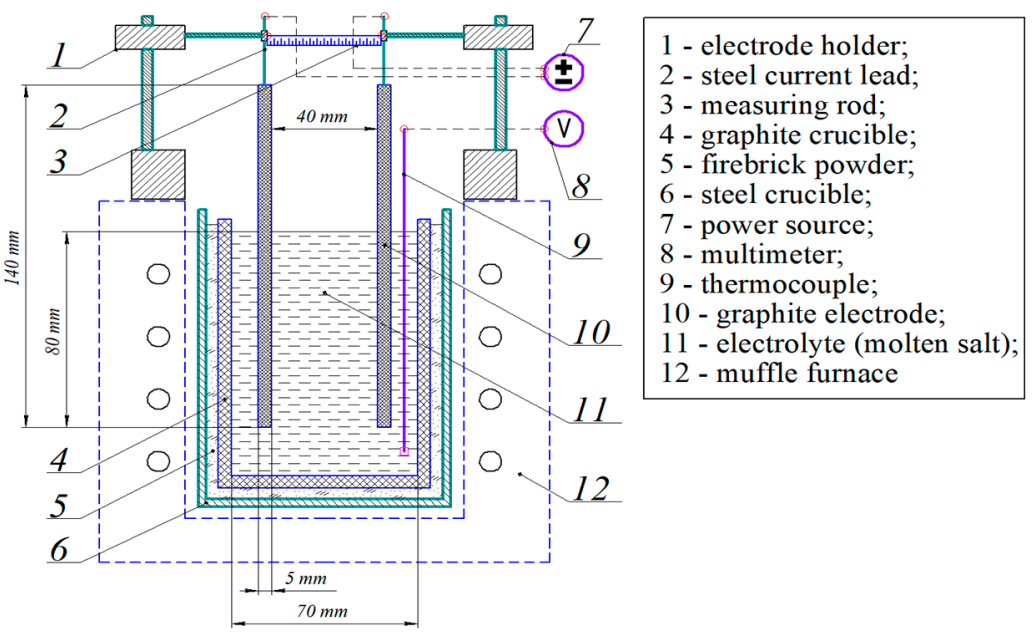

Figure 2. Scheme of the electrochemical cell.

The electrodes were supplied with an electric current of a given density (I-const.). The change in the voltage on the electrochemical cell due to the addition of alumina to the melt was recorded until it reached a constant value. As an electrolyte composition close to the industrial electrolyte was used ( $5 \mathrm{wt} \%$ of $\mathrm{Al}_{2} \mathrm{O}_{3} ; 95 \mathrm{wt} \%$ of $\mathrm{Na}_{3} \mathrm{AlF}_{6}$ (2.7 cryolite ratio)), the melting point of this electrolyte 
was within the range of $945-960{ }^{\circ} \mathrm{C}$ [27]. To avoid melt freezing due to alumina addition $(5 \mathrm{wt} \%)$, the experiment was carried out at an electrolyte temperature of $1100^{\circ} \mathrm{C}$.

The experiment was carried out at $0.5-1.0 \mathrm{~A} / \mathrm{cm}^{2}$ current densities and at $4 \mathrm{~cm}$ of interelectrode distance.

\section{Results and Discussion}

The main reactions of kaolin clays during hydrochloric acid leaching were Equations (1) and (2):

$$
\begin{gathered}
\mathrm{Al}_{2} \mathrm{O}_{3} \cdot 2 \mathrm{SiO}_{2} \cdot 2 \mathrm{H}_{2} \mathrm{O}+6 \mathrm{HCl} \rightarrow 2 \mathrm{AlCl}_{3}+2 \mathrm{SiO}_{2} \downarrow+5 \mathrm{H}_{2} \mathrm{O}, \\
\mathrm{Me}_{\mathrm{x}} \mathrm{O}_{\mathrm{y}}+2 \mathrm{yHCl} \rightarrow \mathrm{xMeCl}_{(2 \mathrm{y} / \mathrm{x})}+\mathrm{yH}_{2} \mathrm{O},
\end{gathered}
$$

where $\mathrm{Me}$ is $\mathrm{Fe}, \mathrm{Ca}, \mathrm{K}, \mathrm{Na}, \mathrm{Mg}$.

As shown in Equations (1) and (2), aluminum dissolves in hydrochloric acid to form ACH. The amount of aluminum recovered into the hydrochloric acid solution was $95 \%$. In this case, silica (the main component of kaolin clays) was not dissolved in hydrochloric acid and was separated from the solution by filtration. Other impurities also transferred into the leaching solution with a different extraction value. The composition of the aluminum chloride solution is presented in Table 2.

Table 2. Chemical composition of the hydrochloric acid leaching solution.

\begin{tabular}{cccccccc}
\hline Component & $\mathrm{AlCl}_{3}$ & $\mathbf{F e C l}_{\mathbf{3}}$ & $\mathbf{N a C l}$ & $\mathbf{K C l}$ & $\mathbf{C a C l}_{\mathbf{2}}$ & $\mathbf{M g C l}_{\mathbf{2}}$ & $\mathbf{H C l}$ \\
\hline Content, wt $\%$ & 21.96 & 3.62 & 0.25 & 0.15 & 0.29 & 0.48 & 0.84 \\
\hline
\end{tabular}

After separation from the solid residue, the aluminum chloride solution was subjected to a two-stage crystallization of $\mathrm{AlCl}_{3} \cdot 6 \mathrm{H}_{2} \mathrm{O}$. Selective deposition of $\mathrm{AlCl}_{3} \cdot 6 \mathrm{H}_{2} \mathrm{O}$ crystals occurred during crystallization and most of the metal chloride impurities remained in the solution. Precipitated crystals of $\mathrm{AlCl}_{3} \cdot 6 \mathrm{H}_{2} \mathrm{O}$ were particles with a hexagonal form combined into agglomerates of different sizes (Figure 3) with a grain size of up to 550 microns.
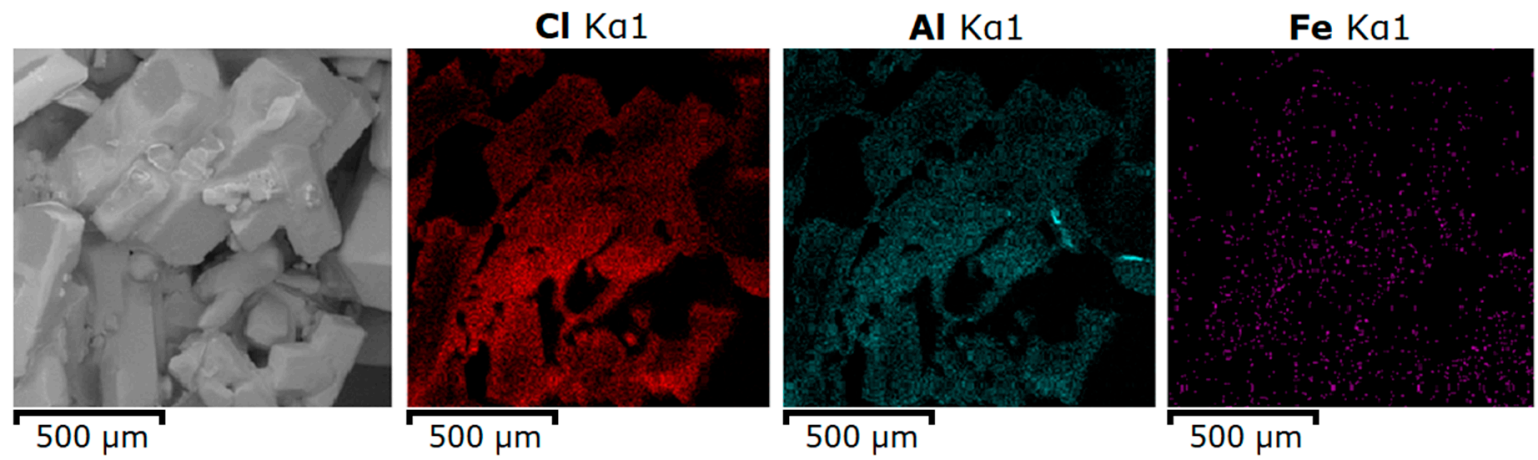

Figure 3. SEM images of aluminum chloride hexahydrate crystals.

The main impurity in the ACH crystals was iron. The main part of the iron was concentrated on the surface of the crystals and was represented by the residual master solution (see Figure 3). At the same time, part of the iron impurities was distributed point-wise throughout ACH crystals volume (see Figure 4 and Table 3). 

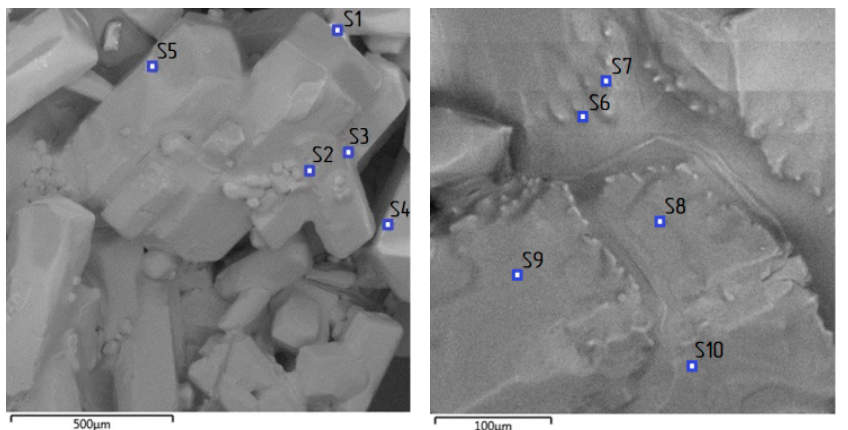

Figure 4. SEM images of aluminum chloride hexahydrate $(\mathrm{ACH})$ with marked micro-XRD spectral analysis points.

Table 3. Micro-XRD spectral analysis results for ACH crystals.

\begin{tabular}{cccccc}
\hline Spectrum Label & $\mathbf{O}$ & $\mathbf{A l}$ & $\mathbf{C l}$ & $\mathbf{F e}$ & Total \\
\hline S1 & 50.66 & 31.89 & 17.03 & 0.42 & 100.00 \\
\hline S2 & 72.43 & 12.58 & 14.97 & 0.02 & 100.00 \\
\hline S3 & 69.69 & 11.22 & 19.03 & 0.06 & 100.00 \\
\hline S4 & 66.74 & 13.83 & 19.33 & 0.1 & 100.00 \\
\hline S5 & 55.06 & 16.69 & 28.20 & 0.05 & 100.00 \\
\hline S6 & 29.83 & 4.26 & 65.91 & 0.00 & 100.00 \\
\hline S7 & 57.84 & 12.70 & 29.37 & 0.09 & 100.00 \\
\hline S9 & 49.08 & 18.46 & 32.41 & 0.04 & 100.00 \\
\hline S10 & 53.38 & 17.00 & 29.58 & 0.04 & 100.00 \\
\hline
\end{tabular}

To determine the temperatures of dehydration, water and chlorine removal, as well as phase transitions, the obtained samples of $\mathrm{ACH}$ were subjected to thermal analysis (see Figures 5 and 6). The measurements were performed on the initial ACH under dynamic heating of the sample up to $1200{ }^{\circ} \mathrm{C}$ at a rate of 10 degrees per minute in an argon atmosphere.

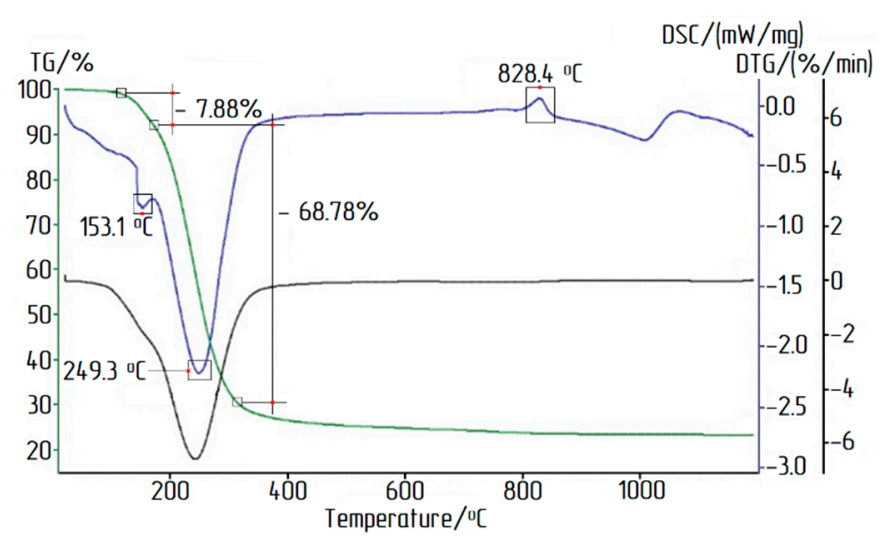

Figure 5. TG/DTA of $\mathrm{AlCl}_{3} \cdot 6 \mathrm{H}_{2} \mathrm{O}$ sample in an argon atmosphere: TG mass loss curve, DTG mass loss rate curve, DSC differential scanning calorimetry curve. 


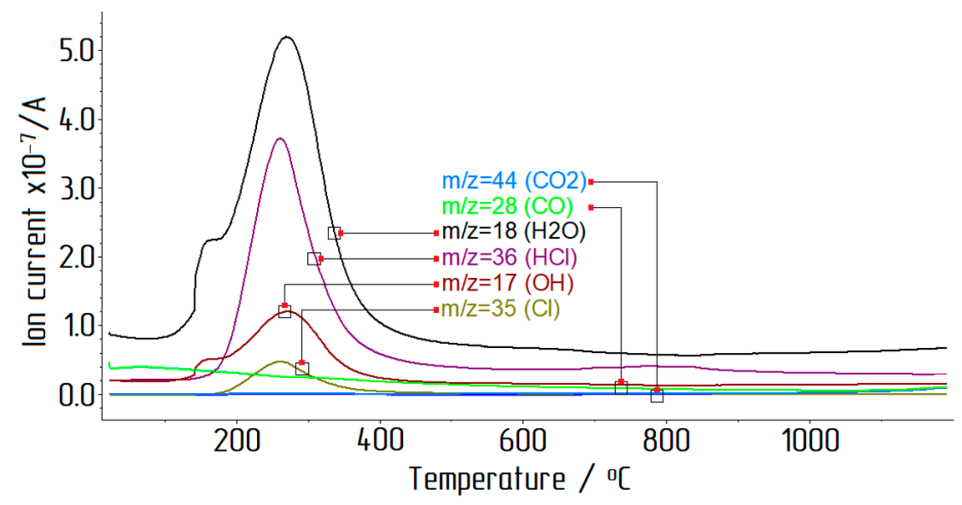

Figure 6. ACH synchronous thermal analysis: mass spectral ion current versus temperature.

The first stage of mass loss occurred between $105^{\circ} \mathrm{C}$ and $156^{\circ} \mathrm{C}$ and was associated with the removal of adsorbed water. Further heating of the sample (up to $1200^{\circ} \mathrm{C}$ ) removed water and chlorine from $\mathrm{AlCl}_{3} \cdot 6 \mathrm{H}_{2} \mathrm{O}$, with a mass loss of $76.66 \%$. The main release of water and chlorine occurred up to $400{ }^{\circ} \mathrm{C}$. At high temperatures, the DSC curve showed an exothermic peak associated with the beginning of $\gamma-\mathrm{Al}_{2} \mathrm{O}_{3}$ to $\alpha-\mathrm{Al}_{2} \mathrm{O}_{3}$ transition. The thermal decomposition reaction of $\mathrm{ACH}$ crystals can be represented by the following Equation (3):

$$
2 \mathrm{AlCl}_{3} \cdot 6 \mathrm{H}_{2} \mathrm{O} \rightarrow \mathrm{Al}_{2} \mathrm{O}_{3}+6 \mathrm{HCl} \uparrow+9 \mathrm{H}_{2} \mathrm{O} \uparrow .
$$

To determine the residual chlorine content in the products of $\mathrm{ACH}$ calcination, $\mathrm{ACH}$ thermal decomposition in a stationary mode at $450-1250{ }^{\circ} \mathrm{C}$ and a duration of $30-90 \mathrm{~min}$ was made. Calcination (in air) was carried out in the RT 50-250/13 tube furnace (Nabertherm GmbH, Lilienthal, Germany). The weight of the $\mathrm{ACH}$ sample was $10 \mathrm{~g}$. The results of the study are presented in Table 4 . The calcination temperature had the most influence on the residual chlorine content in rough alumina. The chlorine content decreased from $7.20 \%$ to $0.12 \%$ with increasing temperature from $450{ }^{\circ} \mathrm{C}$ to $1250{ }^{\circ} \mathrm{C}$ during the $30 \mathrm{~min}$ duration of the calcination process. With increasing duration from 30 to $90 \mathrm{~min}$, the chlorine content reduced from $7.20 \%$ to $4.26 \%$ at the temperature of $450{ }^{\circ} \mathrm{C}$. The minimum chlorine content in alumina $(0.05 \mathrm{wt} \%)$ was obtained at $1250{ }^{\circ} \mathrm{C}$ and $90 \mathrm{~min}$ of calcination. The alumina obtained at $1250{ }^{\circ} \mathrm{C}$ was characterized by an increase in $\alpha-\mathrm{Al}_{2} \mathrm{O}_{3}$ content, which adversely affected the subsequent electrolysis of aluminum. The calcination of $\mathrm{ACH}$ below $900{ }^{\circ} \mathrm{C}$ contributed to an increase of chlorine content in the final product.

Table 4. The dependence of residual chlorine content from the parameters of the calcination.

\begin{tabular}{cccc}
\hline Experiment Code & Temperature, $^{\mathbf{0}} \mathbf{C}$ & Duration, $\mathbf{m i n}$ & Chlorine Content, wt \% \\
\hline 1 & 450 & 30 & 7.20 \\
\hline 2 & 450 & 60 & 6.00 \\
\hline 3 & 450 & 90 & 4.26 \\
\hline 4 & 900 & 30 & 1.70 \\
\hline 5 & 900 & 60 & 0.91 \\
\hline 6 & 900 & 90 & 0.22 \\
\hline 7 & 1250 & 30 & 0.12 \\
\hline 8 & 1250 & 60 & 0.08 \\
\hline 9 & 1250 & 90 & 0.05 \\
\hline
\end{tabular}

According to the results of the thermal analysis of $\mathrm{AlCl}_{3} \cdot 6 \mathrm{H}_{2} \mathrm{O}$ (see Figure 5), studies on the calcination of aluminum chloride hexahydrate crystals were carried out. The studies were conducted 
at three different calcination temperatures for $90 \mathrm{~min}$ each. The chemical compositions of alumina obtained by calcination are presented in Table 5 .

Table 5. Chemical composition of alumina obtained in different modes.

\begin{tabular}{ccccccccc}
\hline Temperature, ${ }^{\circ} \mathrm{C}$ & $\mathrm{Al}_{2} \mathrm{O}_{3}$ & $\mathbf{M g O}$ & $\mathrm{Na}_{2} \mathbf{O}$ & $\mathbf{K}_{\mathbf{2}} \mathbf{O}$ & $\mathrm{CaO}$ & $\mathrm{SiO}_{2}$ & $\mathrm{Fe}_{2} \mathrm{O}_{3}$ & $\mathrm{Cl}$ \\
\hline 800 & 99.362 & 0.043 & 0.003 & 0.010 & 0.028 & 0.005 & 0.015 & 0.534 \\
\hline 900 & 99.678 & 0.047 & 0.003 & 0.007 & 0.029 & 0.007 & 0.020 & 0.209 \\
\hline 1000 & 99.799 & 0.048 & 0.002 & 0.006 & 0.031 & 0.008 & 0.025 & 0.081 \\
\hline
\end{tabular}

Various modifications of alumina were formed depending on the calcination temperature (see Figure 7). Alumina obtained at $800{ }^{\circ} \mathrm{C}$ is mainly represented by $\gamma-\mathrm{Al}_{2} \mathrm{O}_{3}$ with a small fraction of $\delta-\mathrm{Al}_{2} \mathrm{O}_{3}$. Identical peaks were received at $900{ }^{\circ} \mathrm{C}$. At $1000{ }^{\circ} \mathrm{C}$ there was a transition to $\theta-\mathrm{Al}_{2} \mathrm{O}_{3}$ and $\alpha-\mathrm{Al}_{2} \mathrm{O}_{3}$. These results were comparable to previous studies $[28,29]$. As can be seen in Table 5 and Figure 7, an increase in the calcination temperature above $900{ }^{\circ} \mathrm{C}$ led to a decrease in the chlorine content of the final product, but at the same time promoted the transition of $\gamma-\mathrm{Al}_{2} \mathrm{O}_{3}$ to $\alpha-\mathrm{Al}_{2} \mathrm{O}_{3}$, which negatively affected the dissolution of the resulting alumina during electrolysis of aluminum.

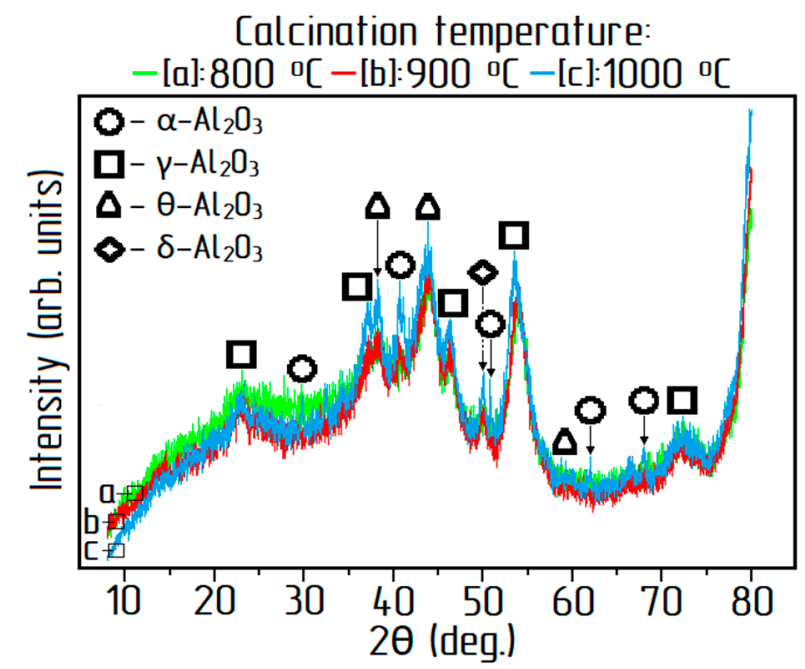

Figure 7. XRD patterns of alumina obtained at $800{ }^{\circ} \mathrm{C}, 900{ }^{\circ} \mathrm{C}, 1000{ }^{\circ} \mathrm{C}$.

To study the effect of temperature conditions on the particle size of alumina, experiments on calcination of $\mathrm{ACH}$ were carried out in two technological modes:

a. With smooth heating of the material to the operating temperature for $2 \mathrm{~h}$, followed by $2 \mathrm{~h}$ of exposure at operating temperature;

b. Thermal shock-placing of the material into a hot furnace with a $4 \mathrm{hr}$ exposure at operating temperature.

The operating temperature of the calcination was $900{ }^{\circ} \mathrm{C}$. The $\mathrm{ACH}$ crystal size subjected to calcination was more than 450 microns. The size distribution of alumina obtained by calcination is shown in Figure 8.

The average size of alumina particles obtained at both temperature modes of calcination was 150 microns. Thus, the particle size decreased by more than three times during $\mathrm{ACH}$ calcination, which can be explained both by the destruction of agglomerates of the initial ACH and primary crystals. According to Figure 8, when the ACH was placed in a hot furnace, there was a slight over-grinding of the material compared to the smooth heating. This was due to the more intense release of the gas phase from the $\mathrm{ACH}$. 


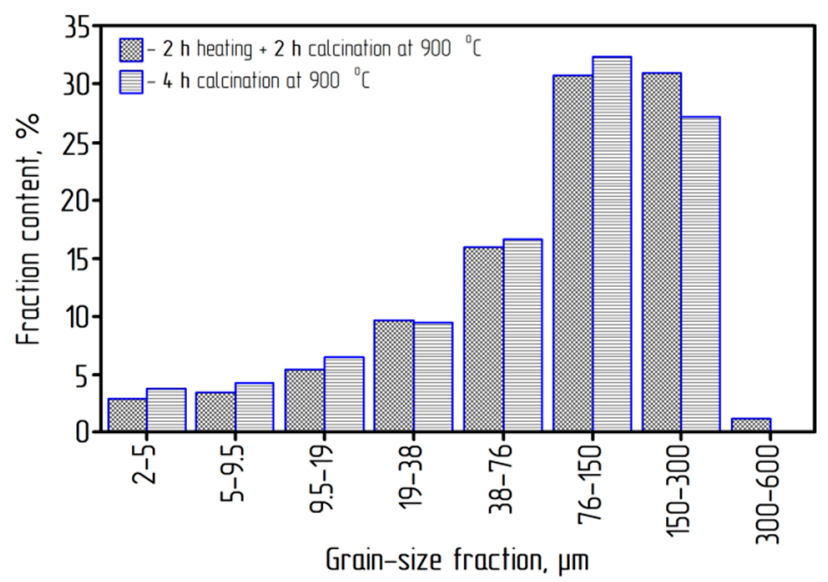

Figure 8. The size distribution of alumina (calcination process at $900{ }^{\circ} \mathrm{C}$ ).

Figure 9 shows SEM images of alumina obtained by hydrochloric acid technology. The samples were obtained by the calcination of aluminum chloride hexahydrate at $900{ }^{\circ} \mathrm{C}$. As can be seen on the figure, the surface of alumina obtained from $\mathrm{ACH}$ was covered by the net of thin cracks emerging from the grain body. These cracks promote the removal process of hydrogen chloride and water vapor. At the same time, crack development was observed in certain directions according to the structural anisotropy of the $\mathrm{AlCl}_{3} \cdot 6 \mathrm{H}_{2} \mathrm{O}$ crystal, without significant destruction of the $\mathrm{ACH}$ particle's original shape. The destruction of $\mathrm{ACH}$ particles during calcination occurred mainly due to the destruction of agglomerates consisting of a large number of fine fractions. In addition, the developed porous surface of alumina obtained from $\mathrm{ACH}$ had a high active surface and promoted adsorption of fluorine-containing waste gases of aluminum electrolysis and increased the rate of alumina dissolution in the electrolyte.
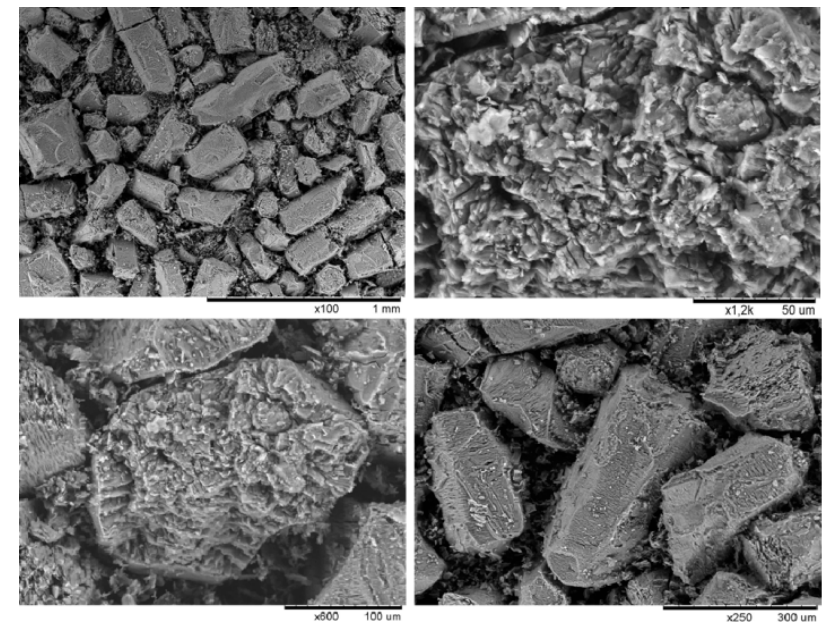

Figure 9. SEM images of alumina obtained by hydrochloric acid technology.

Table 6 shows the compliance of the impurity content in the test samples with the requirements for metallurgical alumina. The content of controlled impurities in test samples of alumina obtained by hydrochloric acid technology met the requirements, which demonstrated the possibility of aluminum electrolysis. 
Table 6. Comparative evaluation of alumina impurities.

\begin{tabular}{ccc}
\hline Component & Average Content, wt \% & Industrial Requirements, wt \% \\
\hline $\mathrm{SiO}_{2}$ & 0.006 & $\leq 0.020$ \\
\hline $\mathrm{Fe}_{2} \mathrm{O}_{3}$ & 0.020 & $\leq 0.030$ \\
\hline $\mathrm{Na}_{2} \mathrm{O}$ & 0.003 & $\leq 0.400$ \\
\hline $\mathrm{K}_{2} \mathrm{O}$ & 0.007 & $\left(\mathrm{Na}_{2} \mathrm{O}+\mathrm{K}_{2} \mathrm{O}\right)$ \\
\hline $\mathrm{TiO}_{2}$ & $<0.001$ & $\leq 0.010$ \\
\hline $\mathrm{CaO}$ & 0.029 & Not specified \\
\hline $\mathrm{MgO}^{-}$ & 0.045 & Not specified \\
\hline $\mathrm{Cl}^{-}$ & 0.21 & Not specified \\
\hline
\end{tabular}

Alumina was produced according to the technological scheme (Figure 1) of kaolin clay processing by the hydrochloric acid technology. The following parameters were used to obtain alumina: leaching temperature was $160^{\circ} \mathrm{C}$ with $3 \mathrm{~h}$ duration. Then, two-stage crystallization of $\mathrm{ACH}$ was carried out: at a temperature of 20 and $80{ }^{\circ} \mathrm{C}$. The duration of both stages was $45 \mathrm{~min}$. In accordance with the studies of $\mathrm{ACH}$ heat treatment, the optimal calcination mode was at $900{ }^{\circ} \mathrm{C}$ and $90 \mathrm{~min}$ duration. The alumina produced satisfied the following properties: $\mathrm{Al}_{2} \mathrm{O}_{3}$ content was $99.7 \mathrm{wt} \%$, the content of impurities didn't exceed maximum allowed values. Alumina was represented by $\gamma$-modification, the average particle size was 150 microns.

To assess the applicability of alumina obtained by the hydrochloric acid method, studies of its solubility in comparison with alumina produced by the classical Bayer process were made. The results of experimental studies are presented in Figure 10.

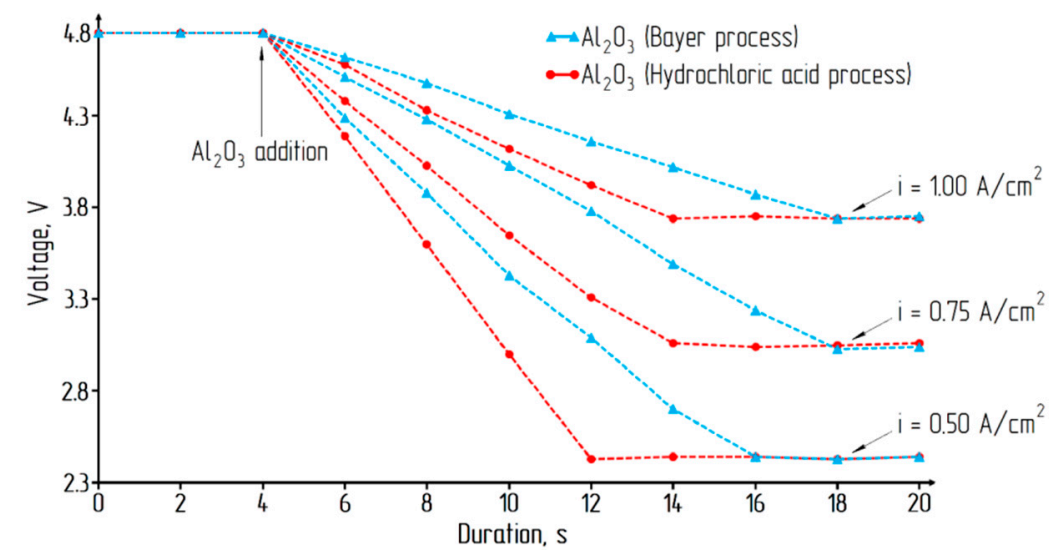

Figure 10. Voltage change in the electrochemical cell.

The achievement of a constant voltage on the electrochemical cell using alumina produced by acid technology occurred on average $4 \mathrm{~s}$ faster, which indicates a better solubility of the alumina in cryolite.

The electrochemical voltage consists of the voltage drop in the electrolyte $\left(U_{1}\right)$, the voltage drop in the contacts and conductors $\left(U_{2}\right)$, decomposition voltage $\left(U_{3}\right)$, and polarization voltage $\left(U_{4}\right)(4)$ :

$$
\mathrm{U}=\mathrm{U}_{1}+\mathrm{U}_{2}+\mathrm{U}_{3}+\mathrm{U}_{4}
$$

Taking into account the small contact area of the current-carrying elements and small amperage, the voltage drop in the contacts and conductors $\left(\mathrm{U}_{2}\right)$ was assumed to be zero. When alumina was added to the cryolite, the electrolysis reaction took the form (5):

$$
\mathrm{Al}_{2} \mathrm{O}_{3}+1.5 \mathrm{C} \rightarrow 2 \mathrm{Al}+1.5 \mathrm{CO}_{2} .
$$


Decomposition voltage $\left(\mathrm{U}_{3}\right)$ in the temperature range of $1000-1100{ }^{\circ} \mathrm{C}$ was $1.15 \mathrm{~V}$ [30]. According to the results [31], the polarization voltage in the system $\mathrm{C}-\mathrm{CO}_{2} \mid \mathrm{Na}_{3} \mathrm{AlF}_{6}$ (2.7-3.1 cryolite ratio) + $\mathrm{Al}_{2} \mathrm{O}_{3} \mid \mathrm{Al}-\mathrm{C}$ at the current density of up to $1 \mathrm{~A} / \mathrm{cm}^{2}$ is in the range of $0.03-0.06 \mathrm{~V}$, with accepted $0.04 \mathrm{~V}$.

The voltage drop in the electrolyte depends on the current density, conductivity of the electrolyte, and interelectrode distance, according to Formula (6):

$$
\mathrm{U}_{1}=\rho \cdot \mathrm{i} \cdot 1,
$$

where $\rho$ is the resistivity of the electrolyte, Om.cm; i is the current density, A/cm²; and 1 is the interelectrode distance, $\mathrm{cm}$.

The resistivity of the electrolyte at the points of voltage stabilization on the electrochemical cell was determined (Table 7).

Table 7. Calculation of the electrolyte resistivity.

\begin{tabular}{|c|c|c|c|}
\hline \multirow{2}{*}{ Parameter } & \multicolumn{3}{|c|}{ Current Density, A/cm² } \\
\hline & 0.50 & 0.75 & 1.00 \\
\hline Decomposition voltage, $\mathrm{V}$ & 1.15 & 1.15 & 1.15 \\
\hline Polarization voltage, $\mathrm{V}$ & 0.04 & 0.04 & 0.04 \\
\hline The voltage drop in the electrolyte, $\mathrm{V}$ & 1.25 & 1.87 & 2.55 \\
\hline Total & 2.44 & 3.06 & 3.74 \\
\hline Resistivity of the electrolyte, $\mathrm{Om} \cdot \mathrm{cm}$ & 0.625 & 0.623 & 0.637 \\
\hline
\end{tabular}

According to Table 7, the resistivity of the used electrolyte, measured using the developed design of the electrochemical cell, was in the range of $0.623-0.637 \mathrm{Om} \cdot \mathrm{cm}$. This value was consistent with the literature data [32,33], which indicates the adequacy of the used method.

\section{Conclusions}

1. In this study, the residual chlorine content at calcination temperatures between $450{ }^{\circ} \mathrm{C}$ and $1250^{\circ} \mathrm{C}$ with a duration between $30 \mathrm{~min}$ and $90 \mathrm{~min}$ was studied. The minimum chlorine content in alumina of $0.05 \mathrm{wt} \%$ was obtained at a temperature of $1250{ }^{\circ} \mathrm{C}$ and a calcination duration of $90 \mathrm{~min}$, but the samples were characterized by an increase in the $\alpha$-phase content, which adversely affected the subsequent electrolysis of aluminum. The calcination of $\mathrm{ACH}$ below $900{ }^{\circ} \mathrm{C}$ contributed to an increased chlorine content in the final product. The optimal mode of aluminum chloride hexahydrate calcination was determined as 90 min at $900{ }^{\circ} \mathrm{C}$;

2. During thermal decomposition of ACH crystals, the main part of water and chlorine precipitated during the heating up to $400^{\circ} \mathrm{C}$;

3. The mode of calcination did not significantly affect the size of the obtained alumina. At the same time, the particle size during the calcination of $\mathrm{ACH}$ in both modes of calcination decreased by three times, from 450 microns for $\mathrm{ACH}$ to 150 microns for alumina;

4. The rate of $\mathrm{Al}_{2} \mathrm{O}_{3}$ in $\mathrm{Na}_{3} \mathrm{AlF}_{6}$ dissolution was studied. It was revealed that the dissolution of the alumina test sample in cryolite was faster than alumina obtained by the classical method (Bayer process).

Author Contributions: Conceptualization, V.I.P.; Data curation, V.I.P. and A.Y.N.; Formal analysis, S.S.K.; Investigation, S.S.K. and A.Y.N.; Methodology, S.S.K.; Supervision, A.A.G.; Visualization, D.Y.O.; Writing一original draft, V.I.P. and A.Y.N.; Writing-review and editing, D.Y.O. and A.A.G.

Funding: The work is financially supported by the Russian Science Foundation (RSF), grant NO. 19-79-30025. 
Conflicts of Interest: The authors declare no conflict of interest.

\section{References}

1. Jiang, Y.; Xie, H.; Huang, L.; He, S. A novel technology study of separation silicon from a high silicon bauxite by direct flotation. Adv. Mater. Res. 2012, 524, 924-929. [CrossRef]

2. Cheng, F.; Cui, L.; Miller, J.D.; Wang, X. Aluminum Leaching from Calcined Coal Waste Using Hydrochloric Acid Solution. Miner. Process. Extr. Metall. Rev. 2012, 33, 391-403. [CrossRef]

3. Suss, A.G.; Damaskin, A.A.; Senyuta, A.S.; Panov, A.V.; Smirnov, A.A. The influence of the mineral composition of low-grade aluminum ores on aluminium extraction by acid leaching. Light Metals 2014, 9781118889084, 105-109.

4. Kyriakogona, K.; Giannopoulou, I.; Panias, D. Extraction of Aluminium from Kaolin: A Comparative Study of Hydrometallurgical Processes. In Proceedings of the 3rd World Congress on Mechanical, Chemical, and Material Engineering (MCM'17), Rome, Italy, 8-10 June 2017.

5. Valeev, D.V.; Mansurova, E.R.; Bychinskii, V.A.; Chudnenko, K.V. Extraction of Alumina from high-silica bauxite by hydrochloric acid leaching using preliminary roasting method. IOP Conf. Ser. Mater. Sci. Eng. 2015, 110, 012049. [CrossRef]

6. Al-Zahrani, A.A.; Abdul-Majid, M.H. Extraction of Alumina from Local Clays by Hydrochloric Acid Process. JKAU Eng. Sci. 2009, 20, 29-41. [CrossRef]

7. Zhao, A.; Zhang, T.; Lv, G.; Tian, W. Kinetics of the Leaching Process of an Australian Gibbsitic Bauxite by Hydrochloric Acid. Adv. Mater. Sci. Eng. 2016, 2016, 5813542. [CrossRef]

8. ElDeeb, A.B.; Brichkin, V.N.; Kurtenkov, R.N.; Bormotov, I.S. Extraction of alumina from kaolin by a combination of pyro- and hydrometallurgical processes. Appl. Clay Sci. 2019, 172, 146-154. [CrossRef]

9. Regina, O.A.; Okechukwu, D.O. Kinetic Model for Ukpor Clay Dissolution in Hydrochloric Acid Solution. J. Emerg. Trends Eng. Appl. Sci. 2012, 3, 448-454.

10. Balmaev, B.G.; Kirov, S.S.; Pak, V.I.; Ivanov, M.A. Kinetics of high-temperature hydrochloric leaching of kaolin clays of east-siberian deposits in laboratory conditions and pilot plant tests. Tsvetnye Met. 2018, 3, 38-45. [CrossRef]

11. Lima, P.A.; Angélica, R.; Neves, R. Dissolution kinetics of Amazonian metakaolin in hydrochloric acid. Clay Miner. 2017, 1, 75-82. [CrossRef]

12. Wu, Y.; Li, L.; Li, M. Effect of Pressure on Alumina Extraction from Low-Grade Bauxite by Acid-Leaching Method. Light Met. 2014, 9781118889084, 121-123.

13. Xiao, J.; Li, F.; Zhong, Q.; Bao, H.; Wang, B.; Huang, J.; Zhang, Y. Separation of aluminum and silica from coal gangue by elevated temperature acid leaching for the preparation of alumina and SiC. Hydrometallurgy 2015, 155, 118-124. [CrossRef]

14. Zhang, L.; Wang, H.; Li, Y. Research on the extract $\mathrm{Al}_{2} \mathrm{O}_{3}$ from coal gangue. Adv. Mater. Res. 2012, 524, 1947-1950. [CrossRef]

15. Demopoulos, G.P.; Li, Z.; Becze, L.; Moldoveanu, G.; Cheng, T.C.; Harris, B. New Technologies for $\mathrm{HCl}$ Regeneration in Chloride Hydrometallurgy. World Metall.-ERZMETALL 2008, 61, 89-98.

16. Brown, C.J.; Olsen, D.R. Regeneration of hydrochloric acid pickle liquors by crystallization. In Proceedings of the Third International Symposium on Iron Control in Hydrometallurgy, Montreal, QC, Canada, 1-6 October 2006; pp. 831-843.

17. Guo, Y.; Lv, H.; Yang, X.; Cheng, $\mathrm{F} . \mathrm{AlCl}_{3} \cdot 6 \mathrm{H}_{2} \mathrm{O}$ recovery from the acid leaching liquor of coal gangue by using concentrated hydrochloric inpouring. Sep. Purif. Technol. 2015, 151, 177-183. [CrossRef]

18. Cheng, H.; Zhang, J.; Lv, H.; Guo, Y.; Cheng, W.; Zhao, J.; Cheng, F. Separating $\mathrm{NaCl}$ and $\mathrm{AlCl}_{3} \cdot 6 \mathrm{H}_{2} \mathrm{O}$ crystals from acidic solution assisted by the non-equilibrium phase diagram of $\mathrm{AlCl}_{3}-\mathrm{NaCl}-\mathrm{H}_{2} \mathrm{O}(-\mathrm{HCl})$ salt-water system at $353.15 \mathrm{~K}$. Crystals 2017, 7, 244. [CrossRef]

19. Linnikov, O.D.; Rodina, I.V.; Grigorov, I.G.; Polyakov, E.V. Kinetics and Mechanism of Spontaneous Crystallization of Potassium Nitrate from Its Supersaturated Aqueous Solutions. Cryst. Struct. Theory Appl. 2013, 2, 16-27.

20. Guo, Y.; Yang, X.; Cui, H.; Cheng, F.; Yang, F. Crystallization behavior of $\mathrm{AlCl}_{3} \cdot 6 \mathrm{H}_{2} \mathrm{O}$ in hydrochloric system. Huagong Xuebao/CIESC J. 2014, 65, 3960-3967. 
21. Wang, J.; Petit, C.; Zhang, X.; Cui, S. Phase equilibrium study of the $\mathrm{AlCl}_{3}+\mathrm{CaCl}_{2}+\mathrm{H}_{2} \mathrm{O}$ system for the production of aluminum chloride hexahydrate from Ca-Rich Flue Ash. J. Chem. Eng. Data 2016, 61, 359-369. [CrossRef]

22. Zhang, N.; Yang, Y.; Wang, Z.; Shi, Z.; Gao, B.; Hu, X.; Tao, W.; Liu, F.; Yu, J. Study on the thermal decomposition of aluminium chloride hexahydrate. Can. Metall. Q. 2018, 57, 235-244. [CrossRef]

23. Hartman, M.; Trnka, O.; Šolcova, O. Thermal Decomposition of Aluminum Chloride Hexahydrate. Ind. Eng. Chem. Res. 2005, 44, 6591-6598. [CrossRef]

24. Yurkov, A. Refractories for Aluminum: Electrolysis and the Cast House, 2nd ed.; Springer International Publishing: Cham, Switzerland, 2017; p. 276.

25. Lysenko, A.P.; Kirov, S.S.; Selnitsyn, R.S.; Nalivayko, A.Y. Influence of calcined anode blocks design on gas outlet efficiency and technical indices of aluminium electrolysis process. Tsvetnye Met. 2013, 9, 114-117.

26. Lysenko, A.P.; Tarasov, V.P.; Nalivayko, A.Y.; Selnitsyn, R.S. Obtaining of rare-earth metals by electrolysis method. Tsvetnye Met. 2013, 11, 71-74.

27. Lacassagne, V.; Bessada, C.; Florian, P. Structure of high-temperature $\mathrm{NaF}-\mathrm{AlF}_{3}-\mathrm{Al}_{2} \mathrm{O}_{3}$ melts: A multinuclear NMR study. J. Phys. Chem. B 2002, 106, 1862-1868. [CrossRef]

28. Nalivaiko, A.Y.; Lysenko, A.P.; Pak, V.I.; Ivanov, M.A. Feasibility Assessment for Leucosapphire Production from Aluminum Oxide Prepared Electrochemically. Refract. Ind. Ceram. 2018, 55, 80-84. [CrossRef]

29. Vlaskin, M.S.; Grigorenko, A.V.; Zhuk, A.Z.; Lisitsyn, A.V.; Sheindlin, A.E.; Shkol'nikov, E.I. Synthesis of high-purity $\alpha-\mathrm{Al}_{2} \mathrm{O}_{3}$ from boehmite obtained by hydrothermal oxidation of aluminum. High Temp. 2016, 54, 322-329. [CrossRef]

30. Moskvitin, V.I.; Nikolaev, I.V.; Fomin, B.A. Metallurgy of Light Metals; Intermet Engineering: Moscow, Russia, 2005.

31. Kovrov, V.A.; Khramov, A.P.; Zaikov, Y.P.; Shurov, N.I. Effect of the Cationic Composition of Cryolite-Alumina Melts on the Anodic Overvoltage. Russ. J. Electrochem. 2007, 43, 909-919. [CrossRef]

32. Huang, Y.; Lai, Y.; Tian, Z.; Li, J.; Liu, Y.; Li, Q. Electrical conductivity of $\left(\mathrm{Na}_{3} \mathrm{AlF}_{6}-40 \% \mathrm{~K}_{3} \mathrm{AlF}_{6}\right)-\mathrm{AlF}_{3}-\mathrm{Al}_{2} \mathrm{O}_{3}$ melts. J. Cent. South Univ. Technol. 2008, 15, 819-823. [CrossRef]

33. Yang, J.; Li, W.; Yan, H.; Liu, D. Conductivity of KF-NaF-AlF 3 System Low-temperature Electrolyte. In Minerals, Metals and Materials Series; Springer: Cham, Switzerland, 2016; pp. 689-693. 